\title{
Nyelvi kompetencia-elvárások a multikulturális munkaerő piacon
}

\author{
Feketéné Silye Magdolna \\ Debreceni Egyetem Agrártudományi Centrum, \\ Mezőgazdaságtudományi Kar, \\ Agrárszaknyelv Oktatási Központ, Debrecen
}

\section{ÖSSZEFOGLALÁS}

A nyelve(ke)t ismerö munkavállaló jelentős előnyét a nyelvtudással nem rendelkezö versenytársaival szemben aligha vonhatjuk kétségbe. Mi több, számos esetben és egyre általánosabb érvénnyel a szaktudás és a nyelvi kompetenciák együttes birtoklása teszi versenyképessé a sok kultúrájú piacon munkát keresöket. Ezen elvárásnak való megfelelés elsősorban az anyanyelvükként nem világnyelvet beszélö kis népek polgárai számára elengedhetetlen, de az angol nyelvnek a kommunikáció globális lingua franca-jává válásával egyre nélkülözhetetlenebbé válik a nemzetközi munkaerö piac más, nem angol ajkú munkavállalói számára is. Európában az angol nyelv ismerete bizonyos esetekben egyenesen a munkakör betöltésének alapkritériuma lehet (Inman, 1983).

Olyan korba érkeztünk, amelyben a nyelvtudás és a kommunikációs ismeretek lényegesen jelentösebb szerepet kapnak a világ gazdasági, politikai és kulturális szférájában, mint eddig bármikor, söt néhányan biztosra veszik, hogy ez a szerepnövekedés jelentős értékrendbeli változásokat fog elöidézni a társadalmak és az egyének életében is.

Talán nem hiábavaló röviden megvizsgálni az alábbiakban azt, hogy tulajdonképpen mi is történt az utóbbi egy-két évtizedben, ami ennyire reflektorfénybe hozta a nyelvtudás, söt inkább a nyelvi müveltség fontosságát. Érdemes továbbá végiggondolni, hogy ezek a „,örténések" hogyan irják, rendezik át az elvárt nyelvi kompetenciák természetét - és hogyan helyezödnek át ezzel együtt a nyelvoktatás fókuszai.

(Dolgozatomban nem foglalkozom a nyelvoktatás közoktatási vetületével, megállapitásaim a felsőfokú szakképzésre vonatkoznak.)

\section{SUMMARY}

Proficiency in a foreign language, especially when combined with knowledge of and skills in another professional area, is highly desirable in the multicultural marketplace. Just as business and media have experienced global changes over the last few decades, so, too, has grown the acceptence of English around the world as the lingua franca for economic and scientific exchange. Second language speakers increasingly turn to English as a requirement of international communication. It is more than understandable that in many European companies, proficiency in English may even be a hiring criterion (Inman, 1983). The spread of English thus privileges certain groups of people and may harm others who have less opportunity to learn it.

One can rightly conclude that we are in an age when communicative language skills in English are an indispensible component of literacy. Many claim that this may well entail significant changes in the social and individual values of nations and people.

This paper investigates some of those underlying social and economic processes that have over the past few decades brought English language literacy into the focus of the attention of many researchers and educators. In the framework of the paper, certain issues of the conceptual impact that these changes have (or are presumed to have) on English language education are also discussed.

\section{A gazdasági/társadalmi háttér változása}

Napjainkat az erősödő gazdasági és társadalmi globalizáció integráló kényszere és a nemzeteknek és egyéneknek identitásuk, önrendelkezésük fölötti joguk megörzésére való törekvése között feszülö ellentét jellemzi. Az ezt kísérő paradigmaváltás mögött számos, nagyjából az utóbbi két évtizedben végbemenő változás érhető tetten.

i. Megváltoztak a korábban jellemző munka típusok: a manufakturális és gépi termelö munka helyét jelentős mértékben átveszi a szolgáltatás.

ii. Megváltozott a munkaerő alkalmazásának módja: az egész életre szóló, teljes idős alkalmazás helyett ma már általános a mobilis, részmunkaidőben való alkalmazás.

iii. A korábban valós térben és valós idöben végzett munka az informatika térhódításával egyre látványosabban kerül át virtuális térbe és időbe (Castells, 1996).

iv. A korábban dominánsan monokulturális környezetben végzett munka tekintélyes mértékben multikulturális közegbe került.

v. Az ipargazdaság korának klasszikus szakmai tagolódása eltűnőben van, új szakmák és hozzájuk kapcsolódó új készség- és kompetencia-elvárások jelennek meg, melyek elsajátítása a globális munkaerőpiacon való érvényesülés feltétele.

Mindezek eredményeként a foglalkozás típusok korábbi kék-galléros/fehér-galléros megkülönböztetése sem helytálló ma már, helyette Reich (1991) új klasszifikációt javasol:

Rutin munkát végzök (routine-production service workers), például gyári munkások, szalagmunkások, informatikai routine munkások stb. (Továbbiakban: R1.)

Humán szolgáltatók (in-person service workers), például kórházi személyzet, taxisoför, házgondnok, vendéglátóipari szolgáltatók stb. (Továbbiakban: R2.)

Szimbolikus analisták (symbolic analysts), magasan képzett szellemi foglalkozásúak, például informatikus mérnökök, rendszerszervezők, stratégia- 
gyártók és elemzők, ügyvédek, orvosok, tudósok stb. (Továbbiakban: R3.)

Castells (1996) úgy találja, hogy a szimbolikus analisták társadalmi megbecsülése, jövedelme és munkalehetősége egyre nő, míg a másik két típusú foglalkozás iránti anyagi és társadalmi megbecsülés egyaránt csökken. Úgy véli, ez annak köszönhetö, hogy a szimbolikus analisták döntő szerepet játszanak a (különösen a fejlődő) társadalmak globális gazdaságban való versenyképességének megőrzésében. Ha munkájuk mellé odarendeljük az ahhoz megkívánt akadémiai és kritikai kompetenciákat, valamint az egészet interkulturális kontextusba helyezzük, akkor nyilvánvaló, hogy ezeknek a szakembereknek szaktudásuk mellett igen magas szintü, komplex nyelvi/müveltségi kompetenciákra is szükségük van: kifogástalanul kell tudniuk idegen nyelven meggyőzően írni, előadni, interkulturális környezetben információkat kritikusan értelmezni és feldolgozni, bonyolult tárgyalási és együttmüködési folyamatokat levezényelni, multikulturális teamekben dolgozni vagy azok együttmüködését összehangolni. [Amerikai tapasztalatok szerint az eddig klasszikusan bevándorlóknak szervezett ilyen jellegü nyelvi kurzusokat újabban nem ők, hanem külföldi gazdasági csúcsvezetők, tudósok, kutatók látogatják, akik meglévő funkcionális nyelvtudásukat elégtelennek találják az új gazdasági környezetben való érvényesüléshez (Rosen, 1999)].

Lényegesen nagyobb számú csoportot alkotnak azonban a rutin munkások és a humán szolgáltatók. Nekik más típusú nyelvi/műveltségi kompetenciákra van szükségük, mint a szimbolikus analistáknak, hiszen a munkájuk jellege is más. Az ő esetükben a nyelvi kompetenciák szükebb köre is elégséges lehet a megfelelő munkavégzéshez.

\section{A változások hatása az angol nyelvoktatásra}

$\mathrm{Az}$ eddig elmondottaknak a nyelvoktatás szempontjából értelmezhető legfontosabb üzenete az, hogy napjaink munkavállalói számára erőteljesen felértékelődött a diverzifikált igényeket kielégítő, pragmatikus, foglalkozás típusokhoz kötődő, közvetlen gyakorlati hasznosíthatóságra alkalmas kommunikativ nyelvtudás. Mivel a globális gazdaság „lingua franca"-ja éppenséggel az angol, az ilyen nyelvtudás iránti igény fokozott erővel jelenik meg az angol (szak)nyelvoktatásban, mi több elöidézi az angol nyelv „globalizációját” is (The British Council, 1997).

\section{Mindez azt jelenti, hogy:}

i. A nyelvtudás célból eszközzé vált, az angolt beszélők a nyelvet egyre inkább nem az idegen ajkúanyanyelvü kommunikációs viszonylatban fogják használni, hanem a nem angol anyanyelvüek egymás közötti kommunikációjára.

ii. A nyelvtanár többé nem jelenti a nyelvtanuló számára a megkérdőjelezhetetlen, hiteles nyelvi modell megtestesítőjét (a British English már nem etalon, sőt az American English sem az).

iii. Az elmélyült, a nyelvtani precizitás kialakítására törekvő általános nyelvoktatás helyét átveszi a célorientált (többnyire szakmához, de legalábbis foglalkoztatáshoz kötött) kommunikatív nyelvi képzés.

Ez a nyelvoktatás már messze nem az a generalizált nyelvoktatás, amit évtizedeken át műveltünk, sőt a sok okból bennünket fogva tartó tehetetlenségi erők miatt jószerével ma is müvelünk.

Nagyon valószínü, hogy a 21 . század embere az angolt már sokkal inkább másodlagos, „kommunikációs anyanyelvének” fogja tekinteni, mintsem egy idegen nyelvnek a sok közül (Warschauer, 2000). Hogy ennek reális a valószínűsége, az jól látható az angol birodalom volt gyarmatain. Azt kijelenteni azonban, hogy ez egyértelmüen jó vagy rossz jelenség, nagy könnyelmüség volna. A világ nyelvi sokszínüségének viszonylagos szegényedése nyilvánvalóan nem kívánatos hozadék, de annak a történelmében gyökerező kulturális, értékrendi tartalomnak, amit az angol nyelv hordoz és közvetít, feltétlenül megtermékenyítő hatása van a vele érintkező kultúrákra és vice versa.

iv. Át kell gondolnunk az eddig általánosan elfogadott és generalizáltan alkalmazott nyelvoktatási módszereket, és mielőbb ki kell dolgozni és érvényt kell szerezni egy differenciált gazdasági/társadalmi igények kielégítésére hivatott, a szakképzés hatékonyságát, azzal párhuzamosan futva vagy abba integráltan erősítő szaknyelvoktatási koncepciónak.

v. Amennyiben tendenciaként elfogadjuk, hogy a szakmák strukturálódása új vonalak mentén történik, a szakmákhoz rendelt kompetenciák specifikálódnak, és hogy nemzetközi kontextusban a munkavállalás alapfeltétele az interkulturális müveltségi és a megfelelő nyelvi kommunikációs kompetenciák együttes megléte, akkor a hazai nyelvoktatásnak, különösen a szaknyelvoktatásnak e vonalak mentén is differenciálódnia kell.

A Reich által szimbolikus analistákként aposztrofált felsőszintü intellektuális munkakört betöltők képzése nagy valószínűséggel a(z) (szak)egyetemeken történik. Nekik nyilvánvalóan komplex nyelvi/műveltségi kompetenciákra van szükségük, többre, mint amit a hagyományos hazai nyelvoktatás nyújtani képes.

A másik két reichi foglalkozási típus kifejezetten cél-orientált nyelvi felkészítést igényel, ennek a helye valószínűleg a szakközépiskola, az iskolarendszerü felsőfokú szakképzés, vagy a felnőtt átképzés bizonyos szegmensei. Nekik másra van szükségük, mint amit a mai generalizált nyelvi képzés nyújt.

Külön figyelmet érdemel ebben az összefüggésben az a megfigyelés, hogy az idegen nyelve(ke)t beszélők igen jelentős kognitív előnyökkel rendelkeznek a nyelveket nem 
beszélökkel szemben: jobb a problémamegoldó képességük, kreatívabbak, alkalmazkodóképesebbek, eredményesebbek a tanulási módszereik, az általános intelligencia szintjük magasabb (Marcos, 1998).

\section{A foglalkozás típusok, a nyelvi/múveltségi kompetenciák és a gyakorlati nyelvoktatás kapcsolata}

A továbbiakban röviden ismertetem a Kasper (2000) által megfogalmazott nyelvi/müveltségi kompetenciákat, majd összekapcsolom őket a fent vázolt Reich-i foglalkozás típusokkal. Az összevetések eredményeként meghatározhatók a dominánsan egyes foglalkozás típusokhoz rendelhető kompetenciák, ami igen hasznos útmutatást nyújthat, például, a mindenkori tanulócsoportok tanterveinek és oktatási anyagainak összeállításához.

3.1. Kasper a nyelvtudásra vonatkoztatva a következő müveltségi kompetenciákat (literacy) határozza meg:

i. A funkcionális nyelvi müveltséggel rendelkező személy beszél, ért, olvas, és ír angolul, valamint e készségeit újabb tudás megszerzésének szolgálatába képes állítani.

ii. Az akadémiai nyelvi készségekkel bíró különböző diszciplínákhoz tartozó és különböző műfajú írott vagy hangzó szövegeket tud elemző módon értelmezni, valamint hasonló szövegeket előállítani, tudását képes új ismeretek megszerzése és a tudományos kutatás szolgálatába állítani.

iii. A kritikai nyelvi műveltségü ember értékelni, szelektálni és rangsorolni tudja az idegen nyelven szerzett információkat, valamint képes önálló következtetések levonására és nyelvi megfogalmazására.

iv. A szociokulturális kompetenciák a nyelvi készségek bi- vagy multikulturális kontextusban való alkalmazását, a kommunikáció mindkét irányú sikerességét, következésképpen a sikeres munkavégzést segítik elő.

v. Az elektronikai kompetencia az idegen nyelvü elektronikus forrásoknak és müveleteknek az előbbi négy szint szerinti kezelését biztosítja.

A fenti nyelvi kompetenciák reichi foglalkozási típusokhoz való viszonyát sematikusan a következőképpen foglalhatjuk össze:

A nyelvi/múveltségi kompetenciák és a foglalkozás típusok viszonya

\begin{tabular}{|l|c|c|c|}
\hline \multicolumn{1}{|c|}{ Nyelvi/müveltségi kompetencia } & R1 & R2 & R3 \\
\hline 1. funkcionális & + & + & + \\
\hline 2. akadémiai & & & + \\
\hline 3. kritikai & & $(+)$ & + \\
\hline 4. szociokulturális & + & + & + \\
\hline 5. elektronikai & $(+)$ & + & + \\
\hline
\end{tabular}

Amint látható, foglalkozási típustól függetlenül nélkülözhetetlen a funkcionális és a szociokulturális nyelvi kompetencia, míg az akadémiai, a kritikai és az elektronikai kompetenciák fontossága foglalkozási típustól függően változó. A nyelvtanár olvasatában ez azt jelenti, hogy a nyelvi képzést a nyelvet felhasználó szükségleteinek ismeretében és annak függvényében célszerü meghatározni.

3.2. A fenti, tantervfejlesztési következtetések levonására is alkalmas összefüggés teljesebbé tételére és egyben alátámasztására álljanak itt az Európa Tanács nyelvi portfoliójában a nyelvi kompetenciákról megfogalmazott gondolatok (1998).

A dokumentum készítői úgy látják, hogy minden személy nyelvi kompetenciái több összetevő együttes, a nyelv használatának célhelyzetétől függő arányban való meglétéböl tevődnek össze. Ezek az összetevők:

- a tudás (knowledge, savoir),

- a készségek (skills, savoir-faire),

- az egzisztenciális kompetenciák (existential, savoir etre) és

- a tanulási kompetencia (ability to learn).

Ezeken az általánosságban vett nyelvi kompetenciákon belül a portfolió készítői a kommunikatív nyelvi kompetenciáknak három lényeges összetevőjét látják:

- a lingvisztikai,

- a szociolingvisztikai és

- a pragmatikus kompetenciákat.

A három összetevő közül a szociolingvisztikai kompetenciának központi szerepet tulajdonítanak.

\section{4. Összegzés és következtetés}

A nyelvi müveltségi kompetenciáknak a Kasper-i elméleti és a nyelvi portfolióban megfogalmazott pragmatikus, tehát két különböző aspektusból való megítélése között, az eltérő szempontú csoportosítás és az eltérő terminológia használat ellenére is igen nyilvánvaló a hasonlóság. A különböző terminológiák mögötti tartalmi összecsengés egyértelműen meggyőz bennünket arról, hogy a szociolingvisztikai környezetbe ágyazott, kommunikativ, komplex nyelvi müveltség a szakmai érvényesülés integráns részévé vált, ami következésképpen elkerülhetetlenné teszi azt, hogy az ilyen koncepciójú nyelvoktatás a szakképzésnek is integráns részévé váljon.

Más szavakkal fogalmazva: az általános készségfejlesztő nyelvoktatási koncepció helyét a szakképzésben át kell hogy vegye a kompetencia alapú, szakmai tartalomba ágyazott, feladat-orientált nyelvi felkészités, amely a szakmai és nyelvi ismeretek közlésének kohéziójában kreativitásra, kritikai gondolkodásra nevel, miközben az interkulturális környezetben való érvényesülés müveltségi kompetenciáival is felvértezi a szakmai értelmiség fiatal képviselöit. Nem szabad ugyanakkor megfeledkezni arról, hogy az oktatás során a komplex nyelvi műveltségi kompetenciákat alkotó egyes készségek szövetét egy tanulói csoporton belül mindig fókuszáltan, az adott célcsoport igényeinek megfelelő szinergikus egységben kell megtervezni. 


\section{IRODALOM}

Castells, M. (1996): The Rise of the Network Society, Oxford, UK: Blackwell

Inman, M. E. (1987): How Foreign Language Study can Enhance Career Pissibilities, ERIC Digest, ED289363

Kasper, L. F. (2000): New Technologies, New Literacies, Language Learning and Technology, 2. 4. 105-28.

Marcos, K. M. (1998): Second Language Learning: Everyone Can Benefit, The ERIC Review, 6.

Reich, B. (1991): The work of nations: Preparing ourselves for $21^{\text {st }}$ century, New York, Knopf

Rosen, B. (1999): Why English is big business: Fluency a must for executives, International Herald Tribune, 19. Oct.

Warschauer, M. (2000): The Changing Global Economy and the Future of English Teaching, TESOL Quarterly, 3.

European Language Portfolio (1998): Council of Europe, 3.2.1., 3.2.2.

The British Council (1997): The Future of English? 